\title{
Working the Crevices: Granting Students Authority in Authoritarian Schools
}

Joan F. Goodman

University of Pennsylvania, joang@gse.upenn.edu

Jessica Hoagland

Nadel Pierre-Toussaint

Celeste Rodriguez

Christina Sanabria

Follow this and additional works at: https://repository.upenn.edu/gse_pubs

Part of the Educational Administration and Supervision Commons, and the Education Policy Commons

\section{Recommended Citation}

Goodman, J. F., Hoagland, J., Pierre-Toussaint, N., Rodriguez, C., \& Sanabria, C. (2011). Working the Crevices: Granting Students Authority in Authoritarian Schools. Retrieved from

https://repository.upenn.edu/gse_pubs/244

Goodman, J. F., Hoagland, J., Pierre-Toussaint, N., Rodriguez, C., \& Sanabria, C. (2011). Working in crevices: Granting students authority in authoritarian schools. American Journal of Education, 117(3), 375-398. doi: 10.1086/ 659212

This paper is posted at ScholarlyCommons. https://repository.upenn.edu/gse_pubs/244

For more information, please contact repository@pobox.upenn.edu. 


\title{
Working the Crevices: Granting Students Authority in Authoritarian Schools
}

\author{
Abstract \\ Schools are beset with a serious "alienation gap" between teachers and students that is no less a \\ problem than the "achievement gap." Increasing student voice is thought to be one means to fill the gap, \\ for it activates agency and thereby decreases passivity. The extent of agency ranges from attentive adult \\ listening to strong student leadership. Here we concentrate on distinguishing elements of freedom, \\ power, and authority in the enactment of agency, particularly how these elements can be distributed to \\ students in urban authoritarian schools. In this article, four second-year Teach for America graduate \\ students describe and reflect on their separate initiatives. Following the descriptions, the senior author, in \\ a cross-case analysis, suggests factors associated with successful outcomes-enhanced self-esteem, \\ individual rather than collective pride, careful consideration of the external context, constrained \\ objectives, and the transfer of authority rather than power. We conclude that in troubled, impoverished \\ schools, incremental change in distributing genuine authority is a promising possibility for enhancing \\ school attachment. \\ Disciplines \\ Education | Educational Administration and Supervision | Education Policy

\section{Comments} \\ Goodman, J. F., Hoagland, J., Pierre-Toussaint, N., Rodriguez, C., \& Sanabria, C. (2011). Working in \\ crevices: Granting students authority in authoritarian schools. American Journal of Education, 117(3), \\ 375-398. doi: $10.1086 / 659212$
}




\title{
Working the Crevices: Granting Students Authority in Authoritarian Schools
}

\author{
JOAN F. GOODMAN \\ University of Pennsylvania \\ JESSICA HOAGLAND \\ Saint Joseph's University \\ NADEL PIERRE-TOUSSAINT \\ Audenried High School, Philadelphia \\ GELESTE RODRIGUEZ \\ Grover Washington Middle School, Philadelphia \\ CHRISTINA SANABRIA \\ Legal Services Corporation, Washington, $D C$
}

\begin{abstract}
Schools are beset with a serious "alienation gap" between teachers and students that is no less a problem than the "achievement gap." Increasing student voice is thought to be one means to fill the gap, for it activates agency and thereby decreases passivity. The extent of agency ranges from attentive adult listening to strong student leadership. Here we concentrate on distinguishing elements of freedom, power, and authority in the enactment of agency, particularly how these elements can be distributed to students in urban authoritarian schools. In this article, four second-year Teach for America graduate students describe and reflect on their separate initiatives. Following the descriptions, the senior author, in a cross-case analysis, suggests factors associated with successful outcomesenhanced self-esteem, individual rather than collective pride, careful consideration of the external context, constrained objectives, and the transfer of authority rather than power. We conclude that in troubled, impoverished schools, incremental change in distributing genuine authority is a promising possibility for enhancing school attachment.
\end{abstract}

The fact of student alienation from schools, particularly from crowded, underfinanced urban schools, is well documented (Fullan 2007; Mitra 2007; Newmann 1981; Pace 2003). The forms that student alienation takes are

Electronically published March 15, 2011

American Journal of Education 117 (May 2011)

(C) 2011 by The University of Chicago. All rights reserved.

0195-6744/2011/11703-0003\$10.00 


\section{Working the Crevices}

various. Students deliberately violate school expectations and rules; set up alternative nonacceptable norms; quit school altogether (Swanson 2008 reports a 40 percent dropout rate in urban schools); do not complete assigned work; resist in-class assignments; and, in general, sustain the role of a nonlearner (Kohl 1994). This "alienation gap," we suggest, is no less problematic than the "achievement gap" — and precedes it.

One approach likely to diminish the gap is to increase students' school participation. The student voice movement, initiated in the 1970s as part of the students' rights initiative and strengthened by the recent emphasis on the child-as-consumer (Rudduck 2007), maintains that it is both morally right and educationally effective to take seriously the perspectives of students (Pollard et al. 1997). At the lowest level of agency, students raise issues and offer opinions to teachers who listen attentively (Holdsworth 2000; Mitra 2007). At the next level, teachers respond to what they hear, thereby authorizing student perspectives (Cook-Sather 2002; see also Fullan 2007; Levin 2000, Mitra 2004; Oyler 1996; Pekrul and Levin 2007; and Shor 1996). Agency increases further when students collaborate with adults in addressing school-determined problems and more still when students take the lead in identifying and researching issues (Cook-Sather 2006; Fielding 2001; Holdsworth 2000; Mitra 2004, 2007; Rudduck and Demetriou 2003). Mitra (2007) has labeled the three levels of student voice as listening, collaboration, and leadership. Holdsworth (2000) has identified six levels: speaking out, being heard, being listened to, being seriously listened to, incorporating views into actions, and sharing decision making/implementation. The yield is enhanced agency, belonging, and competence (Mitra 2004; also Cook-Sather 2002; Holdsworth 2000; Rudduck 2007; Ruddock and Demetriou 2003).

While speaking up, making suggestions, critiquing, choosing, collaborating, partnering, and being heard alter the balance of agency - our primary interest - not all kinds of agency are equally effective in achieving student en-

Joan F. GoOdman is coauthor of The Moral Stake in Education: Contested Premises and Practices (2000), Teaching Goodness: Engaging the Moral and Academic Promise of Young Children (2003), and Moral Education: A Teacher-Centered Approach (2004). She is also the author of numerous articles on school discipline, missions, moral education, and childhood disabilities. Jessica HoAGLAND is Saint Joseph's University site director of Breakthrough of Greater Philadelphia, an academic enrichment program for high-achieving students in Philadelphia and Camden, New Jersey. NAdel Pierre-Toussaint is a math teacher at Audenried High School; she is currently pursuing a master's of public and international affairs at the University of Pittsburgh. Celeste Rodriguez is a teacher at Grover Washington Middle School, Philadelphia. Christina SANAbria is the grants coordinator at Legal Services Corporation, Washington, DC. 
gagement and commitment (Cook-Sather 2006; Mitra 2004; Rudduck 2007; Rudduck and Demetriou 2003). For analytic and pragmatic purposes, it is important to refine the nature (as well as the extent) of agency and determine what aspects we want to promote and under what circumstances.

Agency can afford children more freedom (choice), power, or authority, and is often a medley. To the extent that a teacher invites and attends to student choice and initiative, she enhances freedom. Encouraging children to journal independently or to choose books and partners reduces adult coercion while increasing students' freedom and autonomy but not, contrary to Oyler (1996), their power or authority. Power, for the purposes of this analysis, is defined as adults extending responsibilities to students that involve control over events and people, not the opportunity for choice and self-expression. ${ }^{1}$

As classically described by Max Weber (1947), power "is the probability that one actor within a social relationship will be in a position to carry out his own will despite resistance, regardless of the basis on which this probability rests" (152). Power draws closer to authority when there exists "the probability that certain commands (or all commands) from a given source will be [voluntarily] obeyed by a given group of persons" (324). This is a narrower understanding of power than found in much of the student voice literature, where it is often conflated with any increase in attending to student perspectives (Cook-Sather 2002; Mitra 2007). Taking students' perspectives seriously — even accepting a student suggestion - acknowledges her agency and grants her respect and a modicum of autonomy but does not necessarily enhance her power in the Weberian sense, for there is no shift in control if the implementation of the suggestion is co-opted by the teacher (e.g., an assignment has been changed, a field trip is arranged). Yet, where power relations are critical to the social and psychological status of children, receiving it may enhance student motivation more than opportunities for greater self-expression (freedom).

Just as freedom can be given without power, so power can be granted without increasing student freedom, as when, for example, a student becomes a teacher proxy who supervises a class while the teacher attends to an emergency. Power can, however, include freedom, as when a child is assigned to tutor a small group as he sees fit. Agency, even without power, undoubtedly boosts students' enthusiasm for school, but it is important to recognize the desire for power and therefore to separate it from other aspects of agency.

Freedom or power alone is not equivalent to authority. Power is transformed into authority only as consent replaces coercion, that is, when those in control and those who submit voluntarily accept the legitimacy of their respective roles. When students and teachers commit to common norms that embrace the school (or class), considerable authority may be discharged safely by students who, because they and their teachers operate under common principles, are likely to be trusted. Sharing authority with students becomes more prob- 


\section{Working the Crevices}

lematic in environments lacking a collective orientation, but, even in such circumstances, permitting students some power or just an opportunity for selfexpression (freedom) should be possible (Goodman 2010). The child who has delegated responsibility for leading a line, grading homework papers, and keeping the room orderly is more likely to participate cooperatively in these activities than when she is merely subject to a teacher's commands.

In urban schools that operate under tight authoritarian hierarchies, mete out severe discipline to combat pervasive aggression, and share neither collective purposes nor common norms, the student possession of power and authority may do more to counter their disaffection than other forms of agency. Elijah Anderson (1999) describes the aggression displayed by inner-city youth as a product of their perpetual campaign to achieve and maintain "respect," for this is what promises security. Violence is not an end but a means for attaining status. Power can be a socialized alternative to aggression, another way of gaining reputation, of showing one is tough, cool, and confident (Hemmings 2003; Simmons 2002; Willis 1977).

Yet, however important gaining power and authority may be for these youths, it is hard to come by. With limited possibilities for radical change in power arrangements, it seemed prudent to investigate whether small shifts in freedom, power, and authority were possible without changing the larger school ethos. We speculated that, with sufficiently structured opportunities, the latent drive and capacity for independence present in all adolescents could be harnessed into their assumption of responsibilities for a segment of school life.

\section{Method}

The primary investigators were four second-year master's degree students from Teach for America assigned to separate inner-city middle schools or high schools as full-time teachers. The senior author, in whose graduate seminar the students were enrolled, performed the collective cross-case analysis.

The four schools were attended almost entirely by minority (African American and Hispanic) students and qualified for Title I support (at least 40 percent of students enrolled in the free and reduced-price lunch program). The schools were all "underresourced": facilities were defective, teacher and principal turnover was constant, and instructional materials were inadequate - paper and pencils often absent, books in short supply (see Fine et al. 2007). Loudspeaker interruptions and lockdowns punctuated the week, attainment was at rock bottom, and absenteeism ran about fifty percent.

Our work is best described as a collective case study — a "specific, unique, 
bounded system" (Stake 1994, 237; see also Creswell 2007; Stake 1995)— aimed at generating theoretical speculations. The classrooms fit this description: they have roughly comparable pedagogies and goals - in these instances, improvement on high-stake tests - and they are self-contained units that impose common opportunities and restrictions with individual dynamics. Although interventions in the four classrooms were different, designed to match the particular circumstances and teacher, they were iterations of a common inquiry: Could aspects of agency be dispersed from teachers to students? The case studies were designed to take a broad initial hypothesis and, through scrutinized application, provide refined insights. Together they both tested and generated theory.

No claim is made for experimental rigor. The schools were selected by Teach for America based on their Title I designation. Data collection was more impressionistic than systematic, and we provided no validity for the inductive analyses performed. Unlike many case studies, the researchers were both participants and observers, thereby compromising further claims to objectivity. The analogy is more to a recursive collection of therapeutic interventions, with clients posing similar problems, than to a traditional experimental study. What the methodology recognizes is that with school interventions there are often too many nonindependent "variables" to "control," and any effort to do so produces distorted results. The methodology further recognizes that interpretation is always subjective, given investigators' freedom to enact the intervention, construct questions, and interpret responses. There is no such thing as "representative" schools, but out of thick description and dense familiarity with particulars, productive insights can emerge.

Unlike other forms of case studies, ours were not "portraits" (Lightfoot 1983, 1997) or narrative inquiries (Clandin and Connelly 1994) because the teachers deliberately intervened in classroom routines. The study, with its emphasis on low-level provisional theories that become modified as new situations are taken into account, falls within grounded theory methodology (Glaser and Strauss 1967; Strauss and Corbin 1994). Speculations, we acknowledge, have to be provisional "because they embrace the interaction of multiple actors, and because they emphasize temporality and process. . . . They call for exploration of each new situation to see if they fit, how they might fit, and how they might not fit" (Strauss and Corbin 1994, 279).

We examined the data at three levels: the teachers (graduate students) first described their classrooms and attempted intervention, gave illustrations of small successes and significant barriers, and then offered individual commentaries. Finally, the senior author, in a cross-case analysis, looked at how elements of agency (i.e., freedom, power, authority) articulating with context may be distributed to students in inhospitable environments. 


\section{Working the Crevices}

\section{Confronting a Teacher (Objecting): Christina Sanabria (CS)}

I did not want to engage all of my sixth-grade East Middle School students in an experiment on shared authority, for experience had taught me that only a handful of them can be counted on to participate in whole-class discussions and activities. I logged many hours during my first year attempting to implement system overhauls that gave students greater opportunities for participation; they all flopped. I already knew, as a result of a poll I had conducted, that most students do not believe that teachers listen to, or are concerned about, their problems nor do teachers seek student input in making class decisions. I noted that field trips and assemblies were planned with little student input; even the movie for the schoolwide reward ceremony was chosen without their participation. Given this culture, I opted instead to change my "in the moment" decision making around incidents that would allow students opportunities for controlled self-assertion. I do not lament not attempting another massive overhaul, for I have found that a direct impact on a few students is likely to have an indirect impact on all students.

With JJ I had an early opportunity to put these thoughts into practice. When entering my math class one afternoon, JJ realized he had left his book bag in the previous class. He asked me for, and received, permission to retrieve it. Upon returning without his book bag, I noticed he was fuming. He asked, "Miss, do you think it's right for teachers to push kids?" I was tempted to chide him for speaking out of turn and not immediately return to his task, but instead I asked him to hold his thoughts and told him I would check in with him later. When, at the end of the period I did so, JJ explained he had not retrieved his book bag because the previous teacher had refused him classroom entry and had physically shoved him out the door. Without telling me, JJ had already gone to the dean's office to write a formal statement against the teacher, but he was still upset.

After JJ's account, I acknowledged his indignation, reminding him that I was not the one who had trespassed against him. As JJ has a very short temper, I wanted to make sure he did not explode in anger and create a disruption as we talked. Simultaneously, I did want to address his problem. My prior attempts to engage him in dialogue around conflicts had provoked mutterings such as, "Whatever, man! Whatever. Suspend me, I don't care. Teachers hate kids anyway." He also aggressively retaliated. For example, he had the habit of tipping his chair back on its two back feet. One day he tipped too far and fell. A handful of students burst out laughing. JJ was irate. He walked out, dramatically slammed the classroom door, walked back in, navigated the room menacingly making eye contact with everyone, and said, "Who the fuck laughed at me? Was it you, ? Was it you, ? I'm going to beat up 
everyone in this class who was laughing at me. I'm gong to find out who it was and beat you all the fuck up."

Nonetheless, I went out on a limb and asked if he would like me to call the teacher, Mr. B., to schedule an after-school talk. I told JJ that if he wanted, I would go with him. Surprisingly, JJ accepted. Next, I suggested that he write a letter to help him organize his thoughts about what he wanted to say. JJ got to work. Right after class we went to a secluded hallway and met with Mr. B. When JJ read his letter, I was astonished at the contents. He accepted a great deal of responsibility for the incident escalating, admitting that he had pushed past Mr. B. He apologized, saying he had a "heavy hand." Mr. B. accepted JJ's apology and, in turn, made his own. I suggested that we each think of ways that we contributed to the problem.

I consciously tried to provide a model by acknowledging that I had neglected to write JJ a hall pass. I recognized that a note would have helped Mr. B. understand that JJ was, in fact, authorized to return to his room. At the end of the conversation, Mr. B. and JJ both agreed to inform the dean that he should tear up the documents they had each submitted (a pink slip and formal statement, respectively). I think JJ genuinely felt the problem was resolved. Mr. B. and I heaped praise on him for his mature and peaceful problem solving; the dean called his home as well. This resolution of an incident was atypical, not just for JJ but for the adults as well. I cannot overstate the impact its successful outcome had on me. I was heartened that, given my prior experiences with JJ, he had risen to the occasion.

While I was very satisfied with the resolution, I still saw ways for improvement. Conscious of the power imbalance inherent between adults and students, during the conversation I squatted on my legs to be closer to JJ's height. Mr. B. did not do the same. It was just a detail. Nonetheless, the silhouette of the child, looking up at the adult while he spoke, haunted my otherwise agreeable memories. I also sensed that even though JJ got to read his explanatory letter without interruption, Mr. B. still took more airtime, and his tone was didactic. That is, he stayed starchly in his "teacher" role, explaining to JJ why things happened the way they did, trying to get JJ to understand his point of view without seeking to understand JJ's and, even when accepting fault, not really adopting a position of wanting to learn. I say this not as a criticism of Mr. B., whose behavior I admire. Rather, the observation underscores for me how difficult it is to really listen when children address us, how to shift our paradigms from adult-child, authority-subordinate to, at least in this instance, two individuals angered and hurt by one another.

Another concern is that, busy with his writing, JJ did absolutely no math during the afternoon. On this occasion, I am confident that the trade-off was worthwhile, but at least once a week, JJ finds himself in a conflict situation. Perhaps if JJ had ample opportunity to practice responding to interpersonal 


\section{Working the Crevices}

issues as he did with Mr. B., he would eventually become skilled, independent, and efficient at it. On the other hand, he would miss out on considerable instruction in the process. The issue highlights the undue emphasis of the school on the strictly academic and provides an argument for greater instructional freedom. JJ practiced tremendously important skills that day and, invested in writing and preparing his speech, was "on task" the entire time. His writing was also of high quality, perhaps because it was directed to an authentic problem, not a teacher-driven assignment. But the problem remains: JJ's academic performance is already mediocre at best; without restructuring the school's priorities, commitment to this type of problem solving every time an incident occurs might be at a high cost to his math achievement.

\section{Commentary $(\mathrm{CS})$}

Three actors tentatively shifted their customary stance. Whereas an errant student who had forgotten his book bag would have typically been scolded and told to sit down or silenced when he reentered the room, upset after having failed to rescue his book bag, JJ was given the opportunity to do what any of us would have wished for ourselves - attempt to retrieve the loss and get a hearing on a complaint. But it was a close call and could easily have failed. In accepting the offer to talk with Mr. B., write down his plan, and finally apologize, JJ tempered his explosive tendencies and took a measure of personal responsibility. On the other hand, JJ could have wrecked the encounter when he rudely pushed past Mr. B. Another teacher might have reverted to a disciplinary stance and penalized the child for insubordination. Indeed, Mr. B. had written up a pink slip that would have been delivered to the dean without our request to talk.

One does not review this incident without concern for its fragility. Two teachers focused on one child, rather than math instruction, goes against the current educational ethos in which every minute should be devoted to academic achievement. Acting as steward over the multiple steps eventuating in the positive outcome required structuring and oversight. Monitoring will have to continue for quite a while before JJ has confidence in his teachers and the reverse. Furthermore, the incident required a change in authority relationships. The teachers' stance toward the child had to be more open, flexible, and even deferential with decisions adjusted to address JJ's concerns. That shift is foreign to the school climate and uncomfortable for us.

There is much to be undone. JJ is an angry child, and the slightest incident will trigger an outburst. They are destructive for him, his teacher, and the class. Rather than providing a healthy catharsis, as might a tantrum for a toddler, JJ's blowups display to all his lack of control, frustrate his teachers 
who react angrily, and further convince $\mathrm{JJ}$ that he is neither understood nor valued. There is a chance this cycle can be reversed if he is given the opportunity to voice his dissatisfactions before they result in blowups and if teachers consult with him preemptively about how he and they can better manage daily routines.

I want JJ and others like him to accept responsibility for school obligations, both academic and behavioral. I want them to accept roles of leadership and authority over others, but this requires more self-control than such students likely possess. The incident revealed that when I turned just a bit from my usual authoritarian, don't-lose-a-minute-of-instructional-time self, when I listened to and supported JJ's concerns, he too turned a bit. It was a promising start.

\section{Authority Accepted and Lost (Collapse): Jessica Hoagland ( JH)}

A sixth-eighth-grade mentally gifted program (Achieving in Middle School or AIMS) is situated down the hallway on the other side of a double-glass door from my seventh-grade science class in Southwest Elementary School. An encouraging sign, "Achieving in Middle School," hangs in the AIMS hallway, and various student creations are displayed. By contrast, along my area of the hallway for "Achievers," there are holes in the wall, some graffiti, and little to no student work displayed. The AIMS students are held in high esteem by the administration: more is expected, and, in return, more privileges are granted. The AIMS students, for example, may move from class to class without a teacher and occasionally - that rarest of privileges - no line. The Achievers are always supervised by teachers down the same hall.

Against this background, I attempted an experiment in distributed authority. My seventh-grade class had been strongly resisting my authority. I repeatedly told them, to no avail, that I wanted them to succeed and believed they could if only they listened to me. Because they refused to follow rules, I constantly resorted to sanctions including subtracting points from a grade, calling parents and guardians, and making students repeatedly write sentences. But all I achieved was ever-increasing resistance, prompting more sanctions.

I had long noted the power of peers. If one student left the room unexcused, two others followed. New students started off working but, due to social pressures, stopped within two weeks. A student who consistently fought peer pressures by attending to instructions was picked on. I began to talk with selective students who, though often acting as negative forces in the classroom, commanded the attention of their peers. If by appointing them leaders of small groups they were won over, I reasoned, others would follow. As leaders, I explained, they would have the responsibility to uphold the classroom rules, 


\section{Working the Crevices}

maintain order, create a sense of teamwork, and eventually teach students a concept. I would grade each group leader on how well she/he completed the tasks. I would also give a group grade on their collective group performances. The student leaders agreed to the new positions, most feeling very honored to have been chosen. Groups created their own names, made up collective rules based on the guiding framework, and identified a personally binding rule.

The initial reaction was favorable: most students were happy with their groups and accepted the peer leaders I had chosen. Students liked the prospect of receiving a grade for group work and believed it would help their overall grade. One student, not happy with his group, withdrew. He refused to return to class even after we spoke. I asked his group leader to tell him that he was a vital member and much needed. He returned. I thought this success was huge. But as the weeks continued, morale within the groups steadily decreased. Students rejected group grades because some were uncooperative. I had numerous requests to be assigned an individual seat, graded separately, and to vote students out of groups.

Instead of granting these requests, I started a competition. When a group exhibited overall positive behaviors (e.g., assembling on time, taking notes, giving the quiet signal when I asked for it), the group received one point. A team earning 20 points was awarded a prize, starting with a pen or pencil. If a team reached one hundred points, I would buy pizza, soda, and have a lunch party. The teams also suffered group penalties. For example, if one student in a group had not cleaned his area before lunch, then the entire group would have to wait until their teammate was ready. The competition caused a resurgence of team spirit until two groups started falling behind. In one, though the leader was responsible and had good relationships with others, her leadership was challenged by a student who precipitated a disruption every time the group tried to earn a point. In another group, the leader turned negative, disregarding almost all of my requests. Luckily, other students in the group stepped up to the leadership role and were able to ignore her distractions, but morale sank because they were getting penalized for the team leader's performance. The two teams slowly disintegrated, and within a few weeks, the others followed. Gradually, they abandoned any remnant of authority.

\section{Commentary (JH)}

On reflection, my initial problem was the groups' lack of attachment to the guiding framework. Although I thought the rules had been "jointly" created at the beginning of the year, I realize now that consent was weak; the students never fully embraced them. I had simply interpreted their silence as agreement. 
Thus, the group leader's authority was not legitimated by a set of binding norms. Further, we had never discussed what followed when students disobeyed rules. I merely stated that students should enforce the rules in their groups, nothing more. As a result, the group rules fell by the wayside, and negative peer pressure entered the vacuum.

Second, I tried to boost group cohesion by setting up extrinsic incentives: group grades, group penalties, and competition for rewards. These devices could not buttress the authority structure of the groups nor create group loyalty in the absence of internal norms. The slim cooperation we secured, premised solely on common material interests, splintered when one student threatened a group's competitive success. That defection revealed that the groups did not function as teams devoted to common endeavors but as individuals seeking rewards.

Finally, the collapse of authority was related to my class's marginalization and the school authorities' lack of legitimacy. The message from the administration has been that these students are at the low end of the academic spectrum. Obedience was the principal value promoted, and student voices were silenced. The students assimilated me to their negative views of the school. I could not shake their perceptions.

\section{Planning an Assembly (Assembly): Celeste Rodriguez (CR)}

To distribute authority in a school necessitates a preexisting set of common interests, what Kenneth Strike has called a Shared Educational Project (2003) that establishes a sense of community and generates "belonging, loyalty, mutual identification, and trust" (75). Without shared goals, leadership has no legitimacy and no assurance of collaboration.

Teaching at North Middle School is driven by the need to meet standardized test score goals; classes are highly scripted by the district. Students are largely resistant to instruction. They talk and walk out at will; those remaining are often disorderly. The school has the reputation as one of the most violent and unsafe schools in the state. For the past three years, following a child-on-child rape that occurred in a hallway, it has been on the Persistently Dangerous List. On a daily basis, students are arrested, removed from class, and whole classes are held beyond dismissal time for minor misdeeds done by a few (e.g., speaking out of turn, failing to do homework, and tardiness). The school's three sports teams cannot be watched by visitors for fear of fights among children and parents. While there are small neighborhood crews - self-appointed gangs formed through family or neighborhood ties - that sometimes act as safety units (but also fight among themselves), there is no sense of community in or out of school. Adults fear students. In turn, students remain 


\section{Working the Crevices}

unattached, preoccupied with displaying their toughness and standing their ground against adults and peers.

A service-learning project at North Middle School served as an opportunity to establish limited shared goals in my seventh-grade reading and language arts class. Distributing authority from teacher to student would be the most experimental aspect of the initiative as it departs so radically from my normal practice. Through a colleague, I discovered a student-driven curriculum, Need in Deed. Jointly, students decide on a social problem about which they feel strongly and want to learn more. The teacher then facilitates a get-acquainted investigation to explore its causes and effects. Based on the preliminary information, the class selects a focus question to drive the project. The teacher is supposed to leave the planning, decision making, and execution of the project to students, but permitting this degree of independence is challenging in schools where students are viewed with suspicion and have never had such opportunities.

My first task was to establish an atmosphere of safety and trust. I did this by sending the 11 boys to other rooms for independent work once a week, while I kept the 17 girls - who had been engaging in daily fights and gossipfor open discussions about school life. Meanwhile, for three months the class explored 20 different issues, including animal cruelty, homelessness, pollution, and genetically altered foods before alighting on abuse, then narrowed to sexual abuse. Although the topic initially made me uncomfortable, it generated a host of preliminary questions on the causes and consequences of such crimes. Galvanized by the issue, students poured themselves into preliminary research: they looked at videos, read essays written by high school students, and invited speakers. The class decided on their question: How can we inform our school community on the nature of abuse and its negative effects? Our service project consisted of planning and carrying out two assemblies and creating a clothesline (making T-shirts with facts about abuse, ornamenting them with a class logo, and hanging them on a line).

I decided we needed two managers, one for the assembly and one for the clothesline, along with two assistant managers. The students elected the managers from a slate of six who had self-nominated. Each candidate gave a talk on why he or she was best qualified. The victorious candidate for assembly manager was a female student well known for intimidating classmates, screaming obscenities, tantrums, and violence. Last year she was suspended more than a dozen times and arrested repeatedly for "jumpings" (random beatings of kids), breaking and entering, violating city curfew, and gashing another student's face with scissors. In her speech, she promised to work hard on controlling her temper and listening better to others. Given peer endorsement, she readily assumed prosocial authority. The class voted for milder and more academically inclined assistant managers (perhaps imitating what they thought 
I would have done). We met briefly to draw up a list of required jobs and due dates for completing components of the two projects (assembly and clothesline). Jobs included writing informational reports for distribution to other teachers and ads for the school regarding the pending assembly; writing plays, monologues, and poems; rehearsing the plays and interpretive dances; selecting statements to put on the shirts; designing and sewing the logo onto the shirts; and providing invitations, slides, and photographs. As a preemptive strike against managers selecting friends for their groups, each child turned in an index card with two jobs of interest. Based on their talents and requests, the managers conscientiously determined the best placement for each.

During the month before our presentation, students worked up to five hours a week. A hierarchy of communication was set up. The managers reported to me once a week on progress and problems, and only they could come for help. It was the most efficient work I had ever seen my students do-but there were hurdles along the way. The clothesline manager quit after the assembly manager constructively criticized him over how he coached his group. He thought I would accept his resignation without the other students knowing. Instead, I insisted he explain to the class why he was quitting. He did not return to school for a week and was replaced by the assistant manager. Then he publicly resigned. The assembly manager approached me days later and, pulling me into the hallway so as not to alarm the other students, expressed her feelings of betrayal along with fears that the project might not succeed when such a popular leader walked off. This from the formerly outof-control violent student.

A second altercation was precipitated when a student mistakenly sewed a logo on the front rather than the back of a shirt. When a fellow logo creator rudely and loudly pointed out the error, he told the other student to mind her own business and, after she refused, tried to run out of the room. The fleeing child, also prone to uncontrollable behavior, calmly reviewed his embarrassment with me. With support from another student- "Hey, no big deal, just see if you can fix it, and if not, maybe Miss can wash it" - the student returned to his work.

The transformation displayed by a couple of students and the enthusiastic cooperation of the class were paralleled by academic improvement. While students in my other seventh-grade classes not involved in the service project showed academic gains of $2-5$ percent by the third benchmark in December, the students involved in the project gained 14 percent. The class was also awarded best attendance out of the six seventh-grade classes. In the first month of school, the class had ranked 24th out of 24 classes for suspensions. After six months, they were ranked 5 th and maintained this position for three months. While I cannot claim these changes were causally related, my subjective impression was that the class tone shifted during and after the project. 


\section{Working the Crevices}

\section{Commentary (CR)}

I do not believe that doing a social service project or granting students authority alone would have produced these major improvements. It was the combination of students determining their own meaningful and time-consuming project, plus their leadership roles in managing the project, that accounted for the transformation I observed - from angry, resistant students to cooperative ones. Their investment and self-determined participation in the joint project dissipated their usual reactivity to interpersonal slights. That I, the teacher, as well as the administrators, respected and encouraged the students' pursuits enhanced the project's worthiness and their own. Together, the absorbing interest level of the work, its obvious importance, a clear goal requiring mutual assistance, and adult approval, I believe, enabled the students to shift dramatically the quality of their interactions.

An ingredient of their self-respect was my trust. It was a calculated risk. I knew they might sabotage their freedom, but without it, they would be merely working under my supervision - perhaps assuming power but not authority. I handed over my class keys, permitting them access to all locked materials. I gave students passes without questioning their destination. Students who had never spoken to the principal visited his office to give explanations of, and receive permission for, the project.

Most impressive was the radical change in the "bad"-kid-turned-good. Her pride was obvious. She stopped being late and has not been suspended in months, though previously she was late every day and suspended every other week. Her usual combative stance washed away as she committed to a selfchosen activity, was given authority, and received approval and status from adults and teammates. Though this may have been a fleeting reaction or due to events outside of school, and although one manager has not been to school in six weeks, the project nonetheless suggested possibilities.

Finally, important at least to our temporary success was that managers were elected by their classmates rather than chosen by a teacher. The ever-important peer approval was now aligned with, rather than in opposition to, our mutually agreed upon classroom objectives. Had the leaders (or project) been selected by me, it is likely that other students would have undermined, instead of supported, their authority. They would have been like teachers exerting unwanted pressures rather than admired peers.

\section{Academic Authority (Teaching): Nadel Pierre-Toussaint (NP)}

In my ninth-grade algebra class at South High, students tend to be bored and indifferent. I was not sure if transferring power and authority was possible or, 
if possible, whether it would excite and motivate them. It was simple to come up with tasks that involved classroom power: that is, allowing students to perform tasks that I normally fulfill (i.e., take attendance, pass out calculators, assign "on task" grades, check homework). More challenging was finding tasks rich enough to incorporate authority. I decided to experiment with some miniexercises that delegated power or authority to students in grading behavior, assessing work, and teaching a mini-lesson (thereby creating three exercises each with four students). I assumed they would find the assumption of authority more difficult than the assumption of power - merely acting as my deputy without summoning independent initiative.

The students are accustomed to receiving a daily color-coded behavioral grade (green is one point, yellow is zero, red is minus one) based on class norms: being prompt, productive, proactive, professional, and prepared. The behavioral grades are admittedly subjective and require discretion, as does balancing positive and negative actions to determine each student's overall behavioral grade. But just because there is considerable judgment involved in weighting the variables - unlike, for instance, taking attendance - these tasks lend themselves to implementing authority. I selected two students for my initial experiment in grading daily behavior (repeated in a second class section). The first student (power enhancement) was given the class norms checklist and a simple rubric to apply: green for the execution of all norms, yellow for minimal execution of norms, and red for complete noncompliance. Examples of green, yellow, and red, respectively, are helping a classmate and completing the assignment, being tardy and talkative yet finishing the work, and sleeping for the entire period. A second student (authority enhancement) was instructed to use her own discretion in assigning student behavioral grades without any rubric but was to write several sentences explaining the criteria used. Both students were to grade work performance as well.

The second experiment required two students to grade a quiz and give credit for partially correct answers (repeated with a second class section). I gave the first student (power enhancement) a detailed rubric defining all point values and the weights of questions, while I asked the second (authority enhancement) to create her own rubric and justify the grade.

On another occasion, after I had spent two days doing group and independent work on quadratic functions, I noticed my students continued to have difficulty understanding the correct sequence of steps. I wondered if team peer-teaching would help. For my final experiment, I organized two pairs of students. The first pair (power enhancement) was given a scripted lesson: introduce the topic, the "Do Now" questions, review step-by-step notes (provided on chart paper), lead guided practice, and independent practice on a problem. The second pair (authority enhancement) was instructed to introduce the objective and give a sheet with three sample questions for class review if 


\section{Working the Crevices}

they were so inclined. To provide feedback on their experience, all student teachers were given five questions to answer: How did you feel when performing this task? Did you find this task difficult; if so, why? Do you feel like this task has resulted in your becoming more connected to your class? Who do you believe had the more difficult task, you or ? (authority instructors were asked about a peer who had power and the reverse). Is there any other information regarding your experience with this task that you would like to share?

Although this method of acquiring feedback was impressionistic, the results of the three experiments, to my surprise, clearly favored the advantages of giving students authority rather than power, though both increased ownership, fostered investment, and improved academic performance. The students with only power were worried that I would blame them if they failed to complete the task correctly. They found their task unnatural, were uncomfortable reading scripted notes for 30 minutes, and lacked command of the material even though they displayed full comprehension earlier in the week. The presentations of those with authority went more smoothly. They used their own prepared materials and their own judgment in taking questions. The same discrepancies showed up with the grading. When I assigned Eric (power), for example, a strict rubric for grading behavior, he rebelled, commenting that my grading distinctions were murky and confining. For the performance grade he subverted his assigned task, substituting a percent scale rather than my color-coded options. He said, "that's what made sense to me, it was hard for me to grade student work using a one to three scale because I hadn't made it myself." Fatimah, Eric's partner who had been given authority, reported, "I think mine [grading standard] was better than Eric's because mine was more free, so I was able to put my personal opinion down on what I thought people should get."

Both power and authority students appreciated the trust given to them as well as the control they exercised. Ciara commented, "I think I have more control in the class because the teacher trusts me to help her." Having received trust, they were quite determined to be worthy of it. Kareem accepted the grading assignment as his duty declaring, "So, if they deserve the bad grade, they have to get it."

\section{Commentary (NP)}

Going into this experiment, I had two initial fears: Would the student teachers inflate or deflate their peers' attainments, thereby making it impossible to give them authority going forward? Would children exercising authority cause peer resentment? In fact, neither fear was realized. The identification of the student 
teacher with her fellow students created some initial reluctance and pressure around grading, but it was offset by the student teacher assuming the (temporary) instructor role. Perhaps the combination of their status elevation, the receipt of my trust, and their eager acceptance of a new responsibility helped to overcome grading reluctance. In the end, I found that the grades the student teachers gave, even those who graded without a rubric, approximated my own.

While the students clearly perceived the student teachers "as though they were the boss," they also "felt more comfortable asking them [versus a teacher] questions." Despite being in charge, the student teacher appeared to retain a proximity denied to the more formidable real teacher. "I could relate to them teaching me because they were my peers," one commented. "The way they broke down the steps was helpful because they looked at the work the same way I did."

It was clear to me that giving students power or authority increased everyone's involvement, though students with more freedom - to make grading and instruction decisions - had the more valuable experience. I was able to spend more time on instruction and less on behavioral noncompliance and was freer to help students individually. Whether this was partially or exclusively due to the novelty of the experience awaits a longer period of experimentation; it is one I intend to embark on next year.

\section{Cross-analysis (JG)}

How do we explain the unwillingness of Jessica Hoagland's (Collapse) students to maintain authority after a promising beginning; the precarious success of Christina Sanabria's (Objecting) student who, with her backing, confronted a teacher; the remarkable sustained leadership in Celeste Rodriguez's (Assembly) class resulting in a complex assembly presentation; and the painless assumption of teaching authority by Nadel Pierre-Toussaint's (Teaching) students? The obvious answer is that we cannot. The situations are too various and complex, our knowledge too limited. Yet, there are suggestive clues, more bumped into than predicted, that enlarge our picture of how setting and voice interact.

\section{Ego Enhancement}

As we meet these adolescents in their teen years, they seem vulnerable, wary, distrustful, and insecure. They "watch their backs," are quick to take a defensive or aggressive stance, and are remarkably sensitive to any perceived (or misperceived) signs indicating disrespect. Many have lived lives shadowed by 


\section{Working the Crevices}

violence. Margaret Spencer et al. (2003), quoting findings by Fitzpatrick and Boldizar, point out that close to 85 percent of African American youth have seen at least one incident of violence, and for over 43 percent of the children, that incident was murder. Under such conditions, submission to authority is probably the outcome of fear rather than a belief in its legitimacy.

This being so, students are more likely to accept authority when it feeds self-worth - the agency, belonging, and competence Mitra alludes to (2004)particularly for those without prior trusting relationships. The poster child for this assertion is the delinquent-turned-leader in the assembly project. Such transformations have frequently been observed, indicating latent leadership capacities in students who appear most determined to undermine classroom authority (e.g., leadership in the Glenn Mills School for adjudicated delinquents; see Grissom and Dubnov 1989). Their motive to be a centerpiece, to be observed and reckoned with, requires only a slight shift in focus to emerge as leadership. As noted previously, aggression displayed by inner-city youth is linked with their perpetual campaign to achieve and maintain respect and status, for this is what promises security. Those who have it can coerce deference because their ability to combat threats makes them feared, but they are also admired as prime exemplars of fealty to a system of value-based rules (Anderson 1999). The hope is that by allowing them to lead a significant project, hence granting them a modicum of authority, their respect quotient will increase and their need for defiance decrease. In the bad-girl-turned-good case, while formerly she gained respect and self-worth by brazenly undermining expectations of school and society, at least momentarily she achieved respect in her role as assembly champion. As the school and teacher endorsed the assembly, a confluence occurred between what the school wanted of her and what she needed to maintain status.

\section{Individual over Collective}

The students' dispositions do not lend themselves to embracing impersonal, shared classroom norms. Preoccupied with their own safety, physical and psychological; hypersensitive to slights; and preoccupied with maintaining status, the personal is foreground and the communal important only insofar as it serves the personal. Their wary, distrustful orientation is reminiscent of the student from Cluster, a democratic high school established in the mid1970s under the leadership of Lawrence Kohlberg (Poweret al. 1989), who, when confronted with the large amount of stealing in school, responded, "School isn't a place for trusting stuff, even at Cluster. Community or not, if you want something you'll take it" (111-12).

Efforts to generate collective loyalty, without simultaneously enhancing stu- 
dent egos, were frustrated. JH (Collapse) thought she could encourage group loyalty through group competition and rewards, but the students continued to prioritize self-interest. Though the leaders had been carefully selected, they were powerless to counter the disaffection of their peers. Why? Perhaps because, while CR (Assembly) gave the leaders full autonomy and a chance to shine, JH retained the reigns: the group leaders were nonelected, JH did the grading, and there was no terminal event at which they would play a prominent role.

By contrast, the other two projects maintained focus on individual recognition. Being in charge of a math lesson (Teaching) intensified the prominence of the student who was a grader as well as instructor. So too did the experience of confronting a teacher. Along with supporting JJ, CS displayed considerable respect for him by acknowledging that she too had made an error in failing to write a hall pass. As further reinforcement both teachers and the dean "heaped praise" on the child.

Fostering collective loyalty may have to wait for establishing widespread trust between students and adults in charge. Fielding (2001) describes a school (Sharnbrook) where students worked successfully as cohorts for large-scale changes, but teachers supported them through "radical collegiality."

\section{Attending to Context}

Our outcomes suggest the centrality of supportive external environments when shifting authority. A teacher operating in a hostile atmosphere (Collapse) will have a tougher time than a teacher whose project is approved by the administration (Assembly, Objecting) or entirely independent of it (Teaching). Students preparing for the assembly knew they were being encouraged by the external authorities and, indeed, would be featured by them.

The students in JH's Collapse example were doubly alienated: in addition to the usual disengagement of these teenagers from education, they were the "bad" kids of the school, situated just through a set of doors from the "promising" kids. This atmospheric pall made it extremely difficult for JH to establish any of her own authority, let alone transfer it to students. That given these dreadful conditions, they momentarily rallied to peer-led groups is a tribute to the resiliency of youth, but that resiliency was overwhelmed by other conditions - hostile external powers being one.

The extent to which teachers can make changes in their own classrooms without administrative support remains unanswered but is obviously an important matter. Rudduck (2007) has noted that "the potential of student involvement will not be fully realized, and certainly not sustained, if it does not reach out beyond the individual teacher ... to the school as a whole" (601). 


\section{Working the Crevices}

Mitra (2005) describes a staff-initiated and grant-funded reform effort in a California high school characterized by adults and students committed to "joint enterprise, mutual engagement, and shared repertoire" (522). Lacking such ideal contexts, teachers may nonetheless succeed in persuading administrators to cooperate in authority distribution efforts given its promise.

\section{Constrained Objectives}

As a teacher gingerly begins to transfer power or authority, it appears essential to start with a highly bounded, well-planned objective. Recall that in preparation for the sexual abuse assembly, CR met repeatedly with her girl students, who had been "fighting and gossiping," to establish an atmosphere of "safety and trust." She gave them time (from instruction) to discuss their concerns, select a topic of relevance, and vote for the leaders. Furthermore, limited student authority was shaped by, and ended with, a culminating event. Even so, success was precarious, and one leader bolted.

Conditions surrounding the boy in the Objecting example were also carefully orchestrated with a narrow objective. Because prior "system overhauls" had failed, CS deliberately did not distribute widespread authority. She judged her students too alienated and wanted to start small. Her determination was to stay alert and seize any occasion that would strengthen student readiness. When opportunity knocked, she and her student quickly considered how to manage the confrontation, but the decisions were based on extensive prior thinking. CS valorized JJ (and subdued his anger) by talking with him privately and joining in the meeting. Emboldened by this support, he stayed reasonable, although, once again, it was a close call. The Teaching project was also constrained, and the students were well prepared by NP. They were accustomed to her lessons and had her template when they set up their own. They also understood the authority transfer was an experiment with a short terminus.

By contrast, $\mathrm{JH}$, desperate to get her students participating in schoolwork, dove right into establishing groups hoping that by selecting natural leadersalso the most disruptive - and affording them some independence, they would conscientiously work toward establishing personal and collective rules that would bind them all. It was an ambitious undertaking - a plunge into the entirely unfamiliar and, in retrospect, more than the students could manage without greater preparation.

Eventually it may be possible to conceptualize developmental stages of student agency. Is it important to give students practice in speaking out and being heard, the early levels of Holdsworth (2000) and Mitra (2007), before 
they engage in the more heavily participatory levels? Or can the various levels occur simultaneously?

\section{Authority Rather than Power}

Surprisingly, students responded more positively to increments of authority than to power. This was most explicit in the teaching tasks where NP deliberately pitted the two against each other. When they served as a proxy, students continued to feel the judging eye of their teacher and were oriented to her approval rather than to the exercise of autonomous judgment. The challenge to independently plan their lessons and grading system was welcomed. It is worth noting that here, and in the Assembly example, the students had no difficulty accepting the legitimacy of their peers as authorities.

Where students served as teacher substitutes (Collapse) rather than authorities, fellow students became disgruntled; the leaders were not perceived as legitimate. Again, $\mathrm{JH}$ found that she had to select leaders rather than to have them elected. They, in turn, did not have the authority to develop rules with their groups but were instructed to pick from foundational rules laid down the previous fall by the teacher. Group leaders were instructed in how to handle disgruntled students, and students addressed requests and complaints to $\mathrm{JH}$ rather than to the group leader. External rewards and intergroup competition did not compensate for the leaders' lack of legitimate authority. One has the sense that $\mathrm{JH}$, in her precarious situation, had to keep a hovering presence over the leaders lest they misuse or ineffectively use the tentative power they were granted. She simply could not, in contrast to CR, sideline herself while the groups operated independently. A teacher who does not possess legitimate authority is in a poor position to give it away. Because $\mathrm{JH}$ was associated with an administration that disparaged her class, it is hard to imagine how she could have gained legitimacy.

\section{Final Speculations}

The above comments are, of course, merely hunches. In the successful assembly project, we cannot separate the elements - the ego elevation incumbent on being an elected leader, the carefully constrained and self-selected hot topic, the full assumption of autonomous authority, and the encouragement from external sources - not to mention the effects of varying personalities and experiences for which we have not accounted. Just as all the variables appeared favorable for Assembly, so they appeared negative in Collapse. Similarly, they cannot be disaggregated: unelected leaders with minimal power and authority 


\section{Working the Crevices}

were not likely to benefit from much ego enhancement. Goals were amorphous, and the external powers completely nonsupportive, perhaps even hostile.

Nonetheless, we seem to have stumbled inadvertently upon a cautionary tale. If one is to avoid failure and discouragement, it is wise to start small. "Small" means appreciating that the transfer of authority must be accompanied with personal status increments; hence, enterprises aimed solely at the collective good are to be initially avoided. Small means beginning by restricting authority transfers to well-delineated enterprises that have clear objectives and strong preparation. It means being sure that the surrounding context is favorable and that the authority distributed will be perceived as legitimate. But small does not mean using students as proxy teachers, that is, merely extending power. It can include, and perhaps should whenever possible, allowing students to use their own initiatives and judgment. That is, giving them genuine authority. It is critical, as well, to be mindful that offering a student authority is not tantamount to acceptance of that authority. Unless the student perceives the authority as enhancing her status in the eyes of those whose recognition she seeks, it will eventually be rejected (Collapse). The new role will not enhance her status unless it is congruent with the values and interests of those others (e.g., the sexual abuse topic in Assembly).

With these caveats in mind, one wonders, would the outcomes have improved (1) had the groups in collapse been given limited tasks, for instance, in organizing, recording, and evaluating why the classroom was chaotic; (2) had the class, before establishing groups, carefully discussed the qualities sought in leaders and the rules that would guide them; (3) had they, before enacting the new positions, role played and critiqued demonstrations of authority? Yet, we are heartened by discovering that, despite some disappointments, even under the oppressive circumstances of these schools, students and teachers could step out of their accustomed controlling ways and arrive at positions of greater equality and mutual trust with students.

It should not be surprising that the less radical the demand for cultural shifts, the more likely the success. In these circumstances, teachers, if they are to preserve their jobs, can grant students authority only if it is aligned with existing school expectations, and it will succeed only if that authority boosts self-esteem. What matters most to students is gaining and retaining respect by holding valued positions among their peers. Given that goal, it is natural that they will prefer the partial autonomy that comes with authority to loaned power and will follow others whose high status rubs off on the followers rather than submitting to more impersonal gains. 


\section{Goodman et al.}

\section{Note}

1. In schools the term "responsibility" often means deference to teachers, that is, making the "right" (i.e., teacher chosen) choice (as in, "it is your responsibility to raise your hand before speaking"). Here, by contrast, we use the term to mean making voluntary decisions and accepting the consequences for them. In the context of authority, responsibility is intrinsic to one's involvement with, and supervision of, others (as in "I take responsibility for directing a group that is planning an assembly").

\section{References}

Anderson, Elijah. 1999. Code of the Street: Decency, Violence, and the Moral Life of the Inner City. New York: Norton.

Clandin, Jean, and F. Michael Connelly. 1994. "Personal Experience Methods." In Handbook of Qualitative Research, ed. Norman Denzin and Yvonna Lincoln. Thousand Oaks, CA: Sage.

$\rightarrow$ Cook-Sather, Alison. 2002. "Authorizing Students' Perspectives: Toward Trust, Dialogue and Change in Education." Educational Researcher 31:3-14.

$\rightarrow$ Cook-Sather, Alison. 2006. "Sound, Presence, and Power: 'Student Voice' in Educational Research and Reform." Curriculum Inquiry 36 (4): 369-90.

Creswell, John. 2007. Qualitative Inquiry and Research Design: Choosing among Five Approaches. Thousand Oaks, CA: Sage.

$\rightarrow$ Fielding, Michael. 2001. "Students as Radical Agents of Change." Fournal of Educational Change 2:123-41.

Fine, Michelle, Maria Torre, April Burns, and Yasser Payne. 2007. "Youth Research/ Participatory Methods for Reform." In International Handbook of Student Experience in Elementary and Secondary School, ed. Dennis Thiessen and Alison Cook-Sather. Dordrecht: Springer.

Fullan, Michael. 2007. The New Meaning of Educational Change. 4th ed. New York: Teacher's College Press.

Glaser, Barney, and Anselm Strauss. 1967. The Discovery of Grounded Theory: Strategies for Qualitative Research. New Brunswick, NJ: Aldine Transaction.

$\rightarrow$ Goodman, Joan. 2010. "Student Authority: Antidote to Alienation." Theory and Research in Education 8:227-47.

Grissom, Grant, and William Dubnov. 1989. Without Locks and Bars: Reforming Our Reform Schools. Westport, CT: Praeger.

$\rightarrow$ Hemmings, Annette. 2003. "Fighting for Respect in Urban High Schools." Teachers College Record 105:416-37.

$\rightarrow$ Holdsworth, Roger. 2000. "Schools That Create Real Roles of Value for Young People." UNESCO International Prospect 3:349-62.

Kohl, Herbert. 1994. "I Won't Learn from You" and Other Thoughts on Creative Maladjustment. New York: New Press.

$\rightarrow$ Levin, Benjamin. 2000. "Putting Students at the Centre in Education Reform." Fournal of Educational Change 1:155-72.

Lightfoot, Sarah. 1983. The Good High School: Portraits of Character and Culture. New York: Basic Books.

Lightfoot, Sarah 1997. The Art and Science of Portraiture. San Francisco: Jossey-Bass. 


\section{Working the Crevices}

$\rightarrow$ Mitra, Dana. 2004. "The Significance of Students: Can Increasing 'Student Voice' in Schools Lead to Gains in Youth Development?" Teachers College Record 106 (4): 65188.

$\rightarrow$ Mitra, Dana. 2005. "Adults Advising Youth: Leading While Getting Out of the Way." Educational Administration Quarterly 41(3): 520-53.

Mitra, Dana. 2007. "Student Voice in School Reform: From Listening to Leadership." In International Handbook of Student Experience in Elementary and Secondary School, ed. Dennis Thiessen and Alison Cook-Sather. Dordrecht: Springer.

Newmann, Fred. 1981. "Reducing Student Alienation in High Schools: Implications of Theory." Harvard Educational Review 51:546-64.

Oyler, Celia. 1996. Making Room for Students: Sharing the Teacher Authority in Room 104. New York: Teacher's College Press.

$\rightarrow$ Pace, Judith. 2003. "Managing the Dilemmas of Professional and Bureaucratic Authority in a High School English Class." Sociology of Education 76:37-52.

Pekrul, Sharon, and Ben Levin. 2007. "Building Student Voice for School Improvement." In International Handbook of Student Experience in Elementary and Secondary School, ed. Dennis Thiessen and Alison Cook-Sather. Dordrecht: Springer.

Pollard, Andrew, Dennis Thiessen, and Ann Filer. 1997. "Introduction: New Challenges in Taking Children's Curricular Perspectives Seriously." In Children and Their Curriculum, ed. Andrew Pollard, Dennis Thiessen, and Ann Filer. London: Falmer Press.

Power, Clark, Ann Higgins, and Lawrence Kohlberg. 1989. Lawrence Kohlberg's Approach to Moral Education. New York: Columbia University Press.

Rudduck, Jean. 2007. "Student Voice, Student Engagement, and School Reform." In International Handbook of Student Experience in Elementary and Secondary School, ed. Dennis Thiessen and Alison Cook-Sather. Dordrecht: Springer.

Rudduck, Jean, and Helen Demetriou. 2003. "Student Perspectives and Teacher Practices: The Transformative Potential." McGill Fournal of Education 238 (2): 274-88.

Shor, Ira. 1996. When Students Have Power: Negotiating Authority in a Critical Pedagogy. Chicago: University of Chicago Press.

Simmons, Rachel. 2002. Odd Girl Out: The Hidden Culture of Aggression in Girls. New York: Harcourt Brace.

$\rightarrow$ Spencer, Margaret Beale, Davido Dupree, Michael Cunningham, Vinay Harpalan, and Michèle Muñoz-Miller. 2003. "Vulnerability to Violence: A Contextually-Sensitive, Developmental Perspective on African American Adolescents." Fournal of Social Issues 59 (1): 33-49.

Stake, Robert. 1994. "Case Studies." In Handbook of Qualitative Research, ed. Norman Denzin and Yvonna Lincoln. Thousand Oaks, CA: Sage.

Stake, Robert. 1995. The Art of Case Study Research. Thousand Oaks, CA: Sage.

Strauss, Anselm, and J. Corbin. 1994. "Grounded Theory Methodology." In Handbook of Qualitative Research. Thousand Oaks, CA: Sage.

Strike, Kenneth 2003. "Community, Coherence, and Inclusiveness." In The Ethical Dimensions of School Leadership, ed. Paul Thomas Begley and Olaf Johansson. Dordrecht: Kluwer Academic Publishers.

Swanson, Christopher. 2008. Cities in Crisis: A Special Analytic Report on High School Graduation. Bethesda, MD: Editorial Projects in Education Research Center.

Weber, Max 1947. The Theory of Social and Economic Organization. New York: Free Press.

Willis, Paul. 1977. Learning to Labor: How Working Class Kids Get Working Class Jobs. New York: Columbia University Press. 